\title{
A Metal Fabrication and Finishing Foreman Dies After 25 Foot Fall at a Commercial Building Site
}

\author{
Incident Number: $13 \mathrm{KY042}$
}

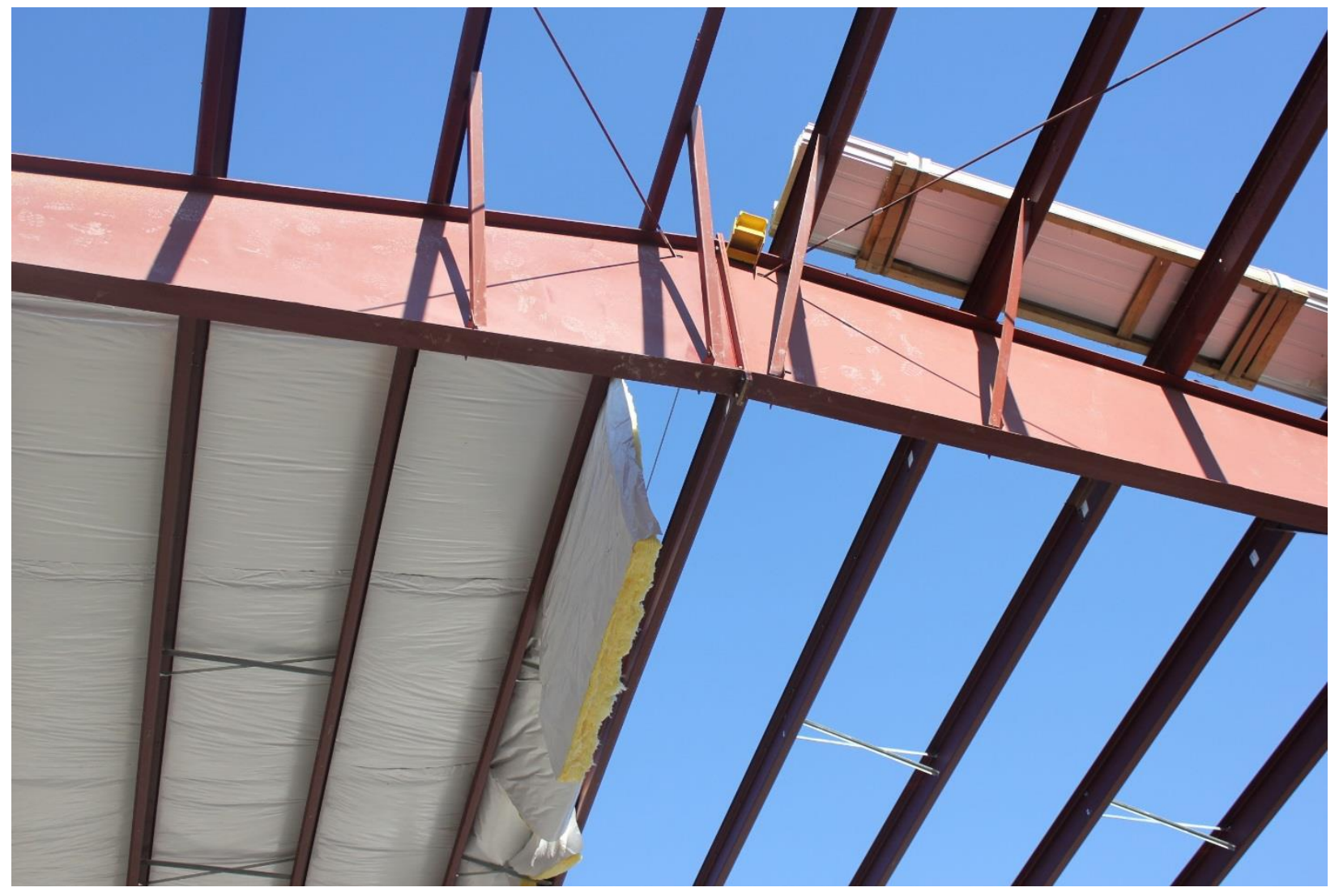

Kentucky Fatality Assessment and Control Evaluation Program Kentucky Injury Prevention and Research Center 333 Waller Avenue Suite 242

Lexington, Kentucky 40504

Phone: 859-323-2981

Fax: 859-257-3909

www.kiprc.uky.edu

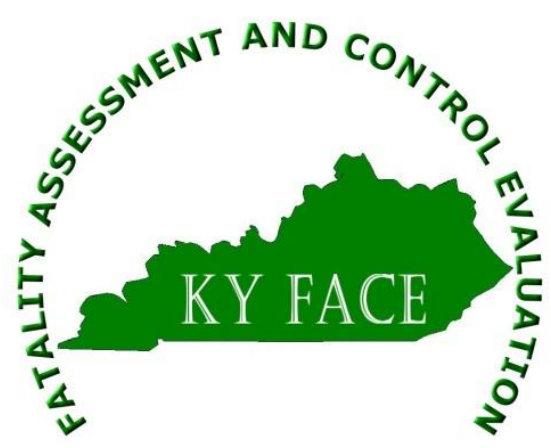




\section{Kentucky Fatality Assessment and Control Evaluation (FACE) Program \\ Incident Number: $13 K Y 042$ \\ Release Date: February 10, 2014 \\ Subject: A Metal Fabrication and Finishing Foreman Dies after 25 Foot Fall at a Commercial Building Site}

\section{Summary \\ On a fall Wednesday afternoon at 3:00 pm, a 53-year-old male fabrication and finishing foreman was installing sheets of insulation prior to decking on a commercial building. The foreman was standing at the edge of the decking on roof beams, arguing with an excavation contractor about the movement of his loader to complete grading work. Witnesses say the foreman was distracted when he told the other workers to spread the "itchy" (meaning rolls of fiberglass insulation). When the foreman took a step forward as he usually did, he fell off the edge and died of head and neck injuries.}

To prevent future occurrences of similar incidents, the following recommendations have been made:

Recommendation No. 1: Employers should always ensure employees have access to tie off when working in high areas allowing employees to remain tied off at all times.

Recommendation No. 2: General Contractors should coordinate and stagger various subcontractors' work to prevent creation of additional hazards, conflict and obstructions

Recommendation No. 3: Employers should be sure safety training is given to each new hire prior to working.

Recommendation No. 4: Employers should implement and enforce a written safety policy which states the consequences of not following their personal fall arrest policy.

Recommendation No. 5: General contractors should ensure through contract language that all subcontractors implement and enforce appropriate safety and health programs and training specific to the work to be performed.

\section{Background}

The foreman on the commercial construction job was hired in July 2013 to supervise the work of the laborers for a metal fabrication and finishing company. The foreman came highly recommended from a competitor company. The foreman had 20 plus years' experience in the industry. The company maintained a safety program and had a consultant perform safety training in January 2013 that included fall protection. The foreman did not participate in that safety training because he was hired in July 2013.

On the day of the incident, the temperature ranged from 84 to 87 degrees Fahrenheit in the afternoon and there was no precipitation, but mostly cloudy skies. 


\section{Investigation}

The Kentucky Fatality Assessment and Control Evaluation Program was notified of an occupational fatality involving a foreman of a commercial construction company by Kentucky Occupational Safety and Health via email.

The employees that were interviewed stated they had been working with a different crew prior to this job and they had worked with this foreman anywhere from two (2) weeks to three (3) months. Employees stated usually when they were working on a job like this, there were no other subcontractors onsite until they were completely finished. They stated this particular job had numerous subcontractors working concurrently, and in their opinion, this was sometimes an unsafe situation for the contractors working below them without hard hats. The employees stated since the onset of this particular job, the subcontractors had been anything but cooperative and had pushed the employees to get out of the way and hurry up and finish. The employees stated the foreman had done his best to keep everyone happy while trying to finish the job safely.

Around three o'clock on the fall afternoon, the foreman on the job was doing leading edge decking work on the west side of a commercial building site. The foreman was standing in the middle of the roof with an employee approximately twenty-five (25) feet to the North of him on the roof. A third roofing employee was standing approximately twenty-five (25) feet to the South on the roof. They were in the process of installing insulation on the roof prior to installing roof decking. The crew had eaten an early lunch and they were near finishing for the day with the insulation, when another subcontractor started yelling at the foreman that his equipment was in the way. The foreman said several times to give his crew 5 more minutes to complete their insulation installation, but the other subcontractor continued to argue with the foreman causing the foreman to become quite frustrated.

A fourth employee of the same company was also on the roof doing clean-up work. All four (4) company employees were wearing fall protection harnesses. The employee doing clean-up work and the employee on the South side were tied off on the roof. They had a life line running across the North and the South sides of the roof. The tie-off stand in the North West corner of the roof had been moved at some point, because it was interfering with the stacking of the decking materials. The employee on the South end tied off to the life line, but the other two (2) employees, the foreman and the North side employee, could not reach the zip line that ran across the length of the roof, and were not tied off.

They thought they were doing the last deck of the day, but two of the three employees on the roof edge could no longer reach the tie-off stand to tie off. Their normal action was for the three employees at the end of the roof to be about four (4) feet from the end of the decking (while tied off), grab the end of the insulation sheet and pull it back taut, then take a step forward while going down to one knee and lay the insulation forward, about two feet beyond the end of the decking. Then the insulation would be pulled tight by two employees on a lift.

It was reported that the foreman was frustrated and angry with another subcontractor about the placement of a backhoe and that he failed to move back four (4) foot from the leading edge of 
the roof. The foreman, not realizing that he hadn't moved to the safe four (4) feet position, then fell twenty-five (25) feet to his death. The foreman struck a hard dirt surface causing substantial trauma to his entire body, but specifically to his head and neck. One of the employees in the boom was the foreman's son who witnessed his father fall to his death. Another employee in the boom called 911 as the remaining employees who were on the roof climbed down. One employee was a trained CPR First Aid provider in the Army and immediately checked for a pulse. He found the pulse on the foreman's right jugular but it immediately stopped. The employee stated from assessing the foreman, he knew there was nothing they could do. When police arrived at 15:07 the foreman had no pulse and was not breathing. He had an obvious broken leg and loss of blood from his head. The paramedics arrived ten minutes later and pronounced him deceased at 15:15 hours. He was then transported by the coroner to the hospital.

\section{Cause of Death}

The cause of death was blunt impact injury to the head and neck.

\section{Recommendations and Discussions}

\section{Recommendation No. 1: Employers should always ensure employees have access to tie off} when working in high areas allowing employees to remain tied off at all times.

The Federal Code of Regulations for steel erection, 29 CFR 1926.760(a) (1) states that workers working at 15 feet and above are required to wear and use a personal fall arrest system. Kentucky law, 803 KAR: 2:417 Section 1(1) (b), states that workers working at 10 feet or higher have to use personal fall arrest systems. Both Federal and KY State regulations were applicable. Standards 29 CFR 1926.760(a)(1) and 803 KAR: 2:417 Section 1(1)(b), state that workers working above 10 feet, with an unprotected edge or side are to be protected from fall hazards by use of guardrails, safety nets, personal fall arrest systems, positioning devices, or fall restraint systems.

\section{Recommendation No. 2: General Contractors should coordinate and stagger various subcontractors' work to prevent creation of additional hazards, conflict and obstructions.}

The General Contractor is responsible to ensure a safe worksite for all subcontractors on the site. By staggering various subcontractors' work, this would allow each subcontractor to fulfill his part of the construction without being in each other's way and avoiding verbal conflict. Overhead work was being done that exposed other contractors on the ground to materials and tools falling and striking them. Under the multi-employer worksite policy, the general contractor can be cited for failure to ensure that all subcontractors follow OSHA guidelines and work in a safe manner.

Recommendation No. 3: Employers should be sure safety training is given to each new hire prior to working. 
Company records show the employer held safety training in January 2013 through a consultant, where fall protection was part of the training. The foreman was not hired until July 2013 and did not attend any type of safety training. The employer should have made sure the foreman received safety training in order to ensure his employees worked safely and led by example.

\section{Recommendation No. 4: Employers should implement and enforce a written safety policy which states the consequences of not following personal fall arrest policies.}

Occupational Safety Health Standard 29 CFR 1926.503(a) (1) states that the employer is responsible for providing a training program for each employee that might be exposed to fall hazards. The company involved in this fatality had written safety procedures and most employees were trained and certified on how to use personal fall arrest systems. All training should be documented, and employees should be required to sign that they understand the safety and training program. Enforcement and consequences for failure to follow safety systems should be part of the standard operating procedures.

A section of the safety policy should include the development of a site-specific safety plan. Occupational Safety and Health Standard 29 CFR 1926(502) (k) (1) states that a fall protection plan shall be prepared by a qualified person and developed specifically for the site where the work is being performed. Employees should conduct a hazard analysis and wear personal protective equipment to prevent injury while working.

\section{Recommendation No. 5: General contractors should ensure through contract language that all subcontractors implement and enforce appropriate safety and health programs and training specific to the work to be performed.}

General contractors should ensure that all subcontractors have safety and health training programs in place that address the tasks their workers are assigned to perform through contract language that requires all subcontractors to identify how they intend to implement a site-specific safety and health program before the initiation of work. The subcontractor's contract should contain clear and concise language describing which party is responsible for a given safety or health issue. Any differences should be negotiated before work begins. Once the provision for these responsibilities has been established, the respective parties should ensure that the provisions of the contract regarding safety and health are upheld through regular inspections of the work site.

\section{Keywords}


Fall protection

Fall prevention

Safety training

Foreman

\section{References}

http://www.osha.gov

https://www.osha.gov/pls/oshaweb/owadisp.show_document?p_table=STANDARDS\&p_id=127

$\underline{51}$

https://www.osha.gov/pls/oshaweb/owadisp.show_document?p_table=STANDARDS\&p_id=106

$\underline{07}$

https://www.osha.gov/pls/oshaweb/owadisp.show_document?p_table=STANDARDS\&p_id=107

$\underline{59}$

https://www.osha.gov/pls/oshaweb/owadisp.show_document?p_table=STANDARDS\&p_id=107 $\underline{58}$

http://www.lrc.ky.gov/kar/803/002/417.htm

http://stopconstructionfalls.com/

\section{Acknowledgements}

The Kentucky FACE program would like to thank the Kentucky Occupational Safety and Health inspector as well as Kentucky Occupational Safety and Health Education and Training Division and the company for their assistance with this report.

The Kentucky Fatality Assessment \& Control Evaluation Program (FACE) is funded by grant 2U60OH008483-09 from the Centers for Disease Control and Prevention and the National Institute for Occupational Safety and Health. The purpose of FACE is to aid in the research and prevention of occupational fatalities by evaluating events leading to, during, and after a work related fatality. Recommendations are made to help employers and employees have a safer work environment. For more information about FACE and KIPRC, please visit our website: www.kiprc.uky.edu 


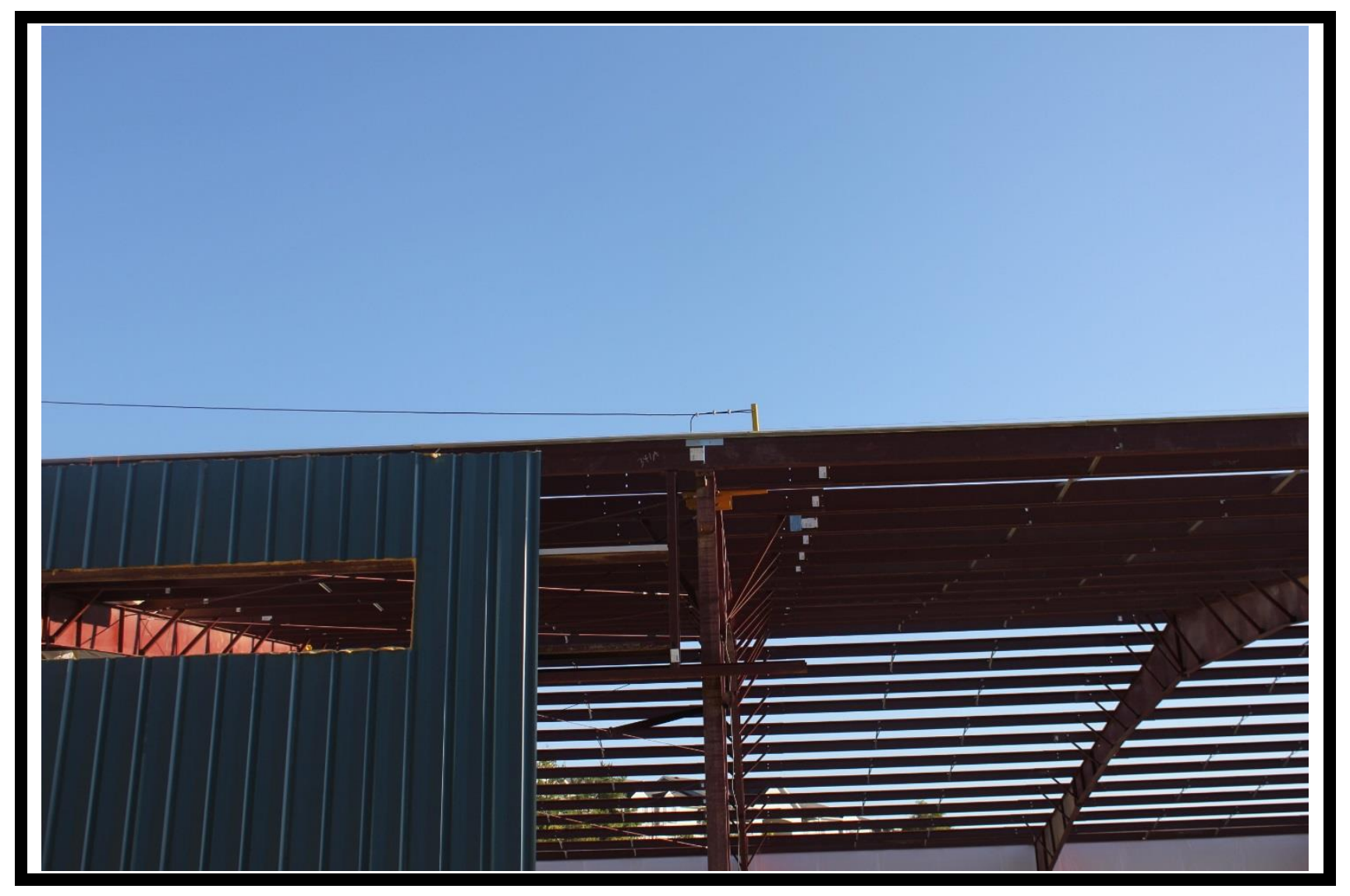

Picture of the steel building with zip line tie-off point. Photograph courtesy of KYOSH 


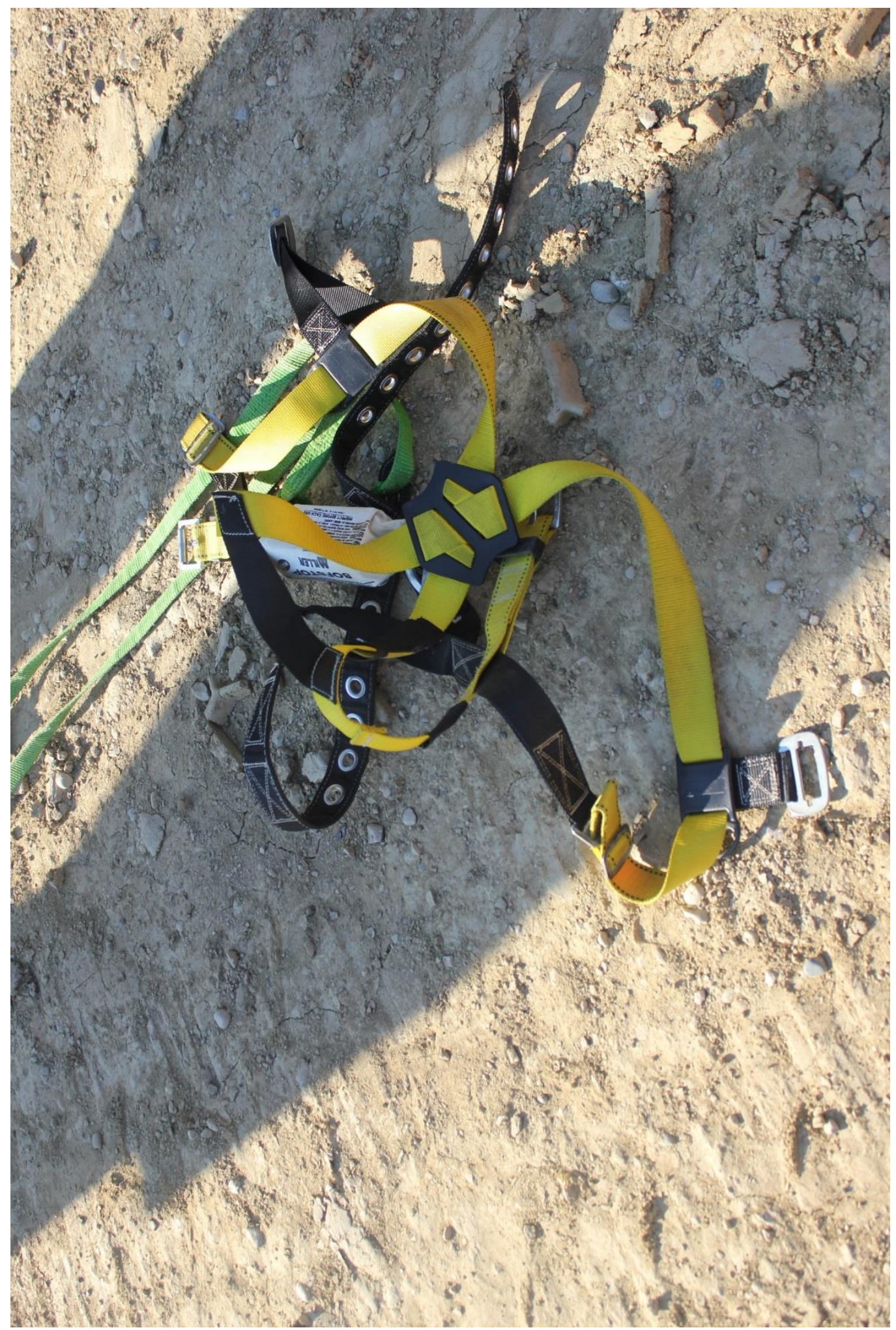

Picture of harness worn by foreman. Photograph courtesy of KYOSH 